\title{
Analisis Dislikes to Subscriber Ratio Youtube Pada 4 Rekomendasi Channel Belajar Bahasa Inggris Terbaik di Youtube Indonesia
}

\author{
Ni Komang Putri Pratiwi \\ komangputripratiwi@gmail.com
}

\begin{abstract}
Youtube is an application in the form of Video Sharing where users can view videos from other users, because Youtube users can upload videos to be enjoyed by other Youtube users or viewers. Youtube is felt to have power or influence in industries, such as social media marketing. The 4 Best English Learning Channel Recommendations on Youtube Indonesia that use Youtube as a marketing platform, namely: Aaron's English, Kampung English LC Language Center, Guruku Mr D, and Sarah Johnson. The purpose of this study is to calculate the credibility of the performance of the Youtube account 4 Recommendations for the Best English Learning Channels on Youtube Indonesia. The method used for this research is quantitative exploratory method. The results of this study indicate that the Kampung English LC Language Center gets the first rank and has good credibility for account performance.
\end{abstract}

\begin{abstract}
ABSTRAK
Youtube merupakan sebuah aplikasi berbentuk Video Sharing dimana pengguna dapat melihat video dari pengguna lainya, karena pengguna Youtube dapat mengunggah video untuk di nikmati oleh para penggunaan Youtube yang lain atau penonton. Youtube dirasakan memiliki kekuatan ataupun pengaruh dalam industry, seperti sosial media marketing. Adapun 4 Rekomendasi Channel Belajar Bahasa Inggris Terbaik di Youtube Indonesia yang memanfaatkan Youtube sebagai platform marketing, yaitu : Aaron's English, Kampung Inggris LC - Language Center, Guruku Mr D, dan Sarah Johnson. Tujuan dari penelitian ini yaitu untuk menghitung kredibilitas dari performa akun Youtube 4 Rekomendasi Channel Belajar Bahasa Inggris Terbaik di Youtube Indonesia. Metode yang digunakan untuk penelitian ini yaitu metode eksploratif kuantitatif. Hasil dari penelitian ini menunjukan bahwa Kampung Inggris LC - Language Center mendapatkan peringkat pertama dan memiliki kredibilitas performa akun yang baik.
\end{abstract}

Keyword : Credibility Account Youtube ; Social Media Marketing ; Social Media Youtube ; Dislikes to Subscribers Ratio; Channel Belajar Bahasa Inggris Terbaik. 


\section{PENDAHULUAN}

Teknologi informasi dan komunikasi saat ini telah berkembang dengan pesat, hal ini membuat semakin banyak jenis aplikasi sosial media yang muncul dengan fitur dan fungsi yang berbeda-beda. Salah satu aplikasi sosial media yang sering digunakan dan memiliki pengaruh besar adalah YouTube. Penelitian ini dilakukan dengan tujuan untuk menemukan rasio-rasio yang terdapat pada channel YouTube. Rasio-rasio ini yang nantinya akan digunakan untuk mengukur performa sebuah akun secara matematis.

Penelitian ini dilakukan dengan menggunakan metode ekploratif untuk menemukan variabel-variabel yang terdapat pada channel YouTube. Variabel tersebut yang nantinya akan dibandingkan dan disandingkan untuk diuji relevansinya sehingga menjadi rasio yang relevan. Rasio yang relevan akan digunakan untuk menilai performa setiap channel yang ada pada sosial media YouTube. Hasil dari penelitian sosial media youtube ini menunjukan bahwa terdapat 6 variabel, variabel tersebut diantaranya yaitu post, subscriber, likes, dislikes, viewers, comments. Keenam variabel tersebut yang nantinya akan dibandingkan dan disandingkan sehingga menemukan 10 rasio yang relevan. Manfaat yang dapat diambil dari penelitian ini yaitu kedepannya dapat menilai, mengukur serta membandingkan kredebilitas dari setiap channel youtube dengan mudah menggunakan 10 rasio yang telah ditemukan. (Hendika Permana, 2021).

Salah satu layanan dari Google ini, memfasilitasi penggunanya untuk meng-upload video dan bisa diakses oleh pengguna yang lain dari seluruh dunia secara gratis. Bisa dikatakan YouTube adalah database video yang paling populer di dunia internet, atau bahkan mungkin yang paling lengkap dan variatif. (Thanissaro \& Kulupana, 2015). Berbagai kalangan umur tertarik untuk menggunakan situs video sharing YouTube, sesuai dengan tema masing-masing dekade umur. (Chandra, 2018). Dilihat dari tingginya jumlah penonton dan pengguna Youtube, wajar jika Youtube menjadi bagian dalam budaya internet. (Arifin, 2016). Banyak channel youtuber terkenal maupun edukasi yang ada pada Youtube, contohnya seperti channel belajar Bahasa Inggris. Adapun channel Youtube 4 Rekomendasi Channel Belajar Bahasa Inggris Terbaik di Youtube Indonesia, diantaranya yaitu : Aaron's English, Kampung Inggris LC Language Center, Guruku Mr D, Sarah Johnson.

Penelitian ini menggunakan metode eksploratif kuantitatif, dan akan menghitung menggunakan rasio-rasio yang ada pada Youtube. Pada penelitian ini menjelaskan bahwa terdapat 10 rasio yang ada pada sosial media Youtube dan relevan digunakan sebagai media ukur kredibilitas channel yang ada. Penelitian ini hanya berfokus untuk menghitung kredibilitas Dislikes to Subscribers Ratio pada 4 Rekomendasi Channel Belajar Bahasa Inggris Terbaik di Youtube Indonesia. Tujuan dari penelitian ini adalah mengetahui kredibilitas performa dari channel Youtube 4 Rekomendasi Channel Belajar Bahasa Inggris Terbaik di Youtube Indonesia menggunakan Dislikes to Subscribers Ratio.

\section{TINJAUAN PUSTAKA}

Perkembangan teknologi informasi di zaman globalisasi saat ini sangatlah cepat. Masyarakat sudah terbiasa menggunakan teknologi informasi dalam kehidupan sehari-hari. Teknologi Informasi adalah suatu teknologi yang digunakan untuk mengolah data. Pengolahan 
itu termasuk menyimpan, menyusun, mendapatkan, memproses, memanipulasi data dalam berbagai cara untuk menghasilkan informasi yang berkualitas, yaitu informasi yang akurat, tepat waktu, dan relevan. Salah satu inovasi teknologi informasi yang sedang trend adalah YouTube.

Youtube merupakan sebuah aplikasi berbentuk Video Sharing dimana pengguna dapat melihat video dari pengguna lainya, karena pengguna Youtube dapat mengunggah video untuk di nikmati oleh para penggunaan Youtube yang lain atau penonton. (Nurhadi, 2020). Konten video yang disajikan di YouTube pun terbilang beragam mulai dari musik, kuliner, fashion, film, trailer film, dokumentasi dan masih banyak lagi. Pengguna juga dapat melihat informasi mengenai berapa banyak view dan berapa banyak yang menyukai dan tidak menyukai video tersebut. Akses untuk berkomunikasi dua arah juga disediakan yakni melalui komentar. (Onainor, 2019).

Dari segi kuantitas penonton, YouTube sudah menyaingi televisi sebagai sarana media yang paling sering diakses orang indonesia. Dari 1.500 responden yang terlibat dalam penelitian, 53\% menyatakan mengakses YouTube setiap hari, dan 57\% menyatakan menonton televisi setiap hari. (Setiadi et al., 2019). Pengguna youtube bahkan cukup beragam dari tingkat anak-anak hingga orang dewasa. (Surandika, 2020).

Youtube merupakan pionir aktivitas kreatif yang bersifat kolektif sekaligus sebagai bagian dari media mainstream melalui internet. Melalui media ini, vlogger (pembuat video blogger) ikut serta dalam pengaruh youtube. (Wirga, 2016). Tidak sedikit orang-orang yang menjadi terkenal hanya dengan meng-upload video mereka di youtube. Oleh karena itu youtube menjadi salah satu pilihan bagi mereka yang ingin mencoba peruntungan. Mulai dari menyanyi atau pun menari bisa menjadi sebuah pilihan. Tidak sedikit artis-arti masa kini yang awalnya terkenal karena youtube. Ambil saja contoh Justin Bieber atau dari negri sendiri seperti Sinta dan Jojo. Mereka bisa berhasil sampai seperti sekarang ini adalah berkat youtube dan juga penggunanya yang membuat video-video mereka menjadi viral dan menarik perhatian para produser rekaman. (Mangole et al., 2017).

Youtube dirasakan memiliki kekuatan ataupun pengaruh dalam industri, sehingga menimbulkan kualitas channel yang menentukan strata maupun kredibilitas pemilik channel. Kredibilitas channel Youtube merupakan suatu hal yang cukup penting untuk berbagai kepentingan. Kredibilitas sebuah channel Youtube dapat diukur dari tingkat performa yang dihasilkan secara matematis. Dalam mengukur performa diperlukan skala pengukuran yang tertuang ke dalam rasio.

\section{METODE PENELITIAN}

Penelitian ini menggunakan metode tipe eksploratif yang akan meneliti kredibilitas dari media Youtube 4 Rekomendasi Channel Belajar Bahasa Inggris Terbaik di Youtube Indonesia. Penelitian ini dapat dijadikan sebagai acuan penelitian kuantitatif sehingga variabel yang akan dianalisis adalah objek yang memiliki nilai berupa angka sehingga memformulasikan sebagai rasio. 
Berikut merupakan uraian langkah yang dapat dilakukan dalam penelitian ini untuk menemukan peringkat pertama akun Youtube Rekomendasi Channel Belajar Bahasa Inggris yang memiliki performa terbaik, diantaranya yaitu :

\section{Melakukan Pencarian Pada Youtube Untuk Menentukan Objek yang Akan Dianalisa.}

Dilakukan langkah awal yaitu melakukan pencarian channel Youtube yang mencakup keseluruhan objek yang akan dianalisa. Setelah data diperoleh, selanjutnya dilakukan analisa pada masing-masing channel Youtube berdasarkan nama-nama channel belajar Bahasa Inggris terbaik di Youtube Indonesia. Pastikan semua channel ada pada aplikasi sosial media Youtube.

\section{Menghitung Nilai Rata-Rata Variabel Dari 4 Rekomendasi Channel Belajar Bahasa Inggris Terbaik di Youtube Indonesia.}

Pada langkah ini, peneliti menghitung nilai variabel Dislikes dan variabel Subscribers. Variabel-variabel yang terdapat pada Youtube tersebut yang nantinya akan dibandingkan dan diuji relevansinya sehingga menemukan sebuah rasio yang relevan. Dengan cara mengambil minimal 10 postingan kemudian dijumlahkan sehingga menemukan nilai rata-rata dari masing-masing variabel.

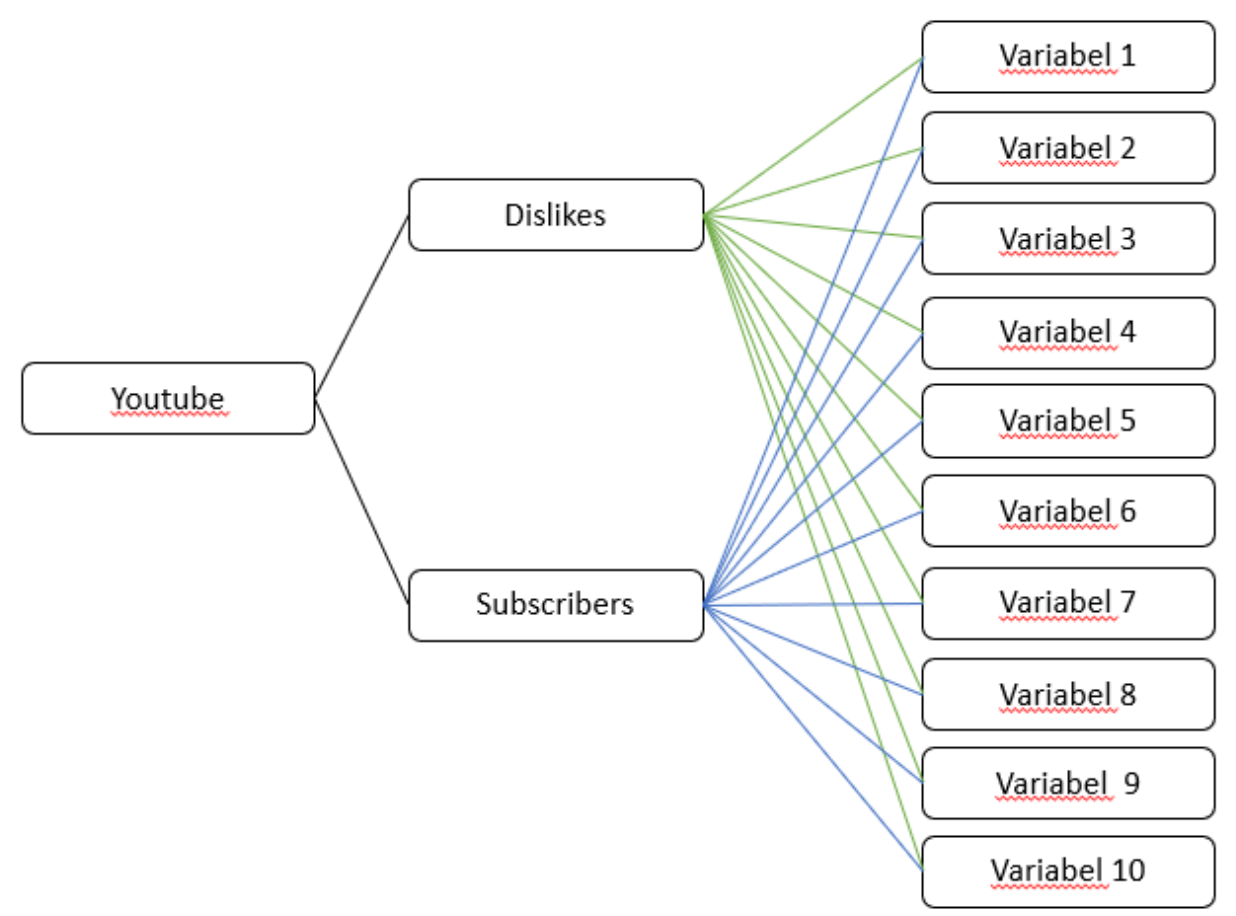

Gambar 1. Analisa Nilai Rata-Rata Variabel

\section{Menghitung Nilai Kredibilitas Rasio}

Untuk menghitung nilai kredibilitas dari variabel Dislikes to variabel Subscribers rasio, peneliti menggunakan cara membagi nilai variabel pertama dengan nilai variabel kedua. Contoh semisal jika variabel Dislikes memiliki nilai 100 dan 
variabel Subscribers memiliki nilai 300, maka cara menghitungnya yaitu $100: 300=$ 0,3 . Dengan begitu nilai dari variabel Dislikes to variabel Subscribers rasio adalah 0,3.

\section{Menentukan Peringkat Pada Channel Youtube}

Pada langkah terakhir yang dilakukan pada penelitian ini yaitu menentukan peringkat pada masing-masing rasio yang ada. Pada penentuan peringkat perlu melihat karakteristik dari rasio yang di analisa. Jika karakteristik rasio merupakan rendah, maka objek yang memiliki nilai terendah akan mendapatkan angka 5 dan objek yang memiliki nilai tertinggi akan mendapatkan angka 1 . Namun jika rasio memiliki karakteritik tinggi maka objek yang mendapatkan nilai tinggi akan mendapatkan angka 1 dan objek yang mendapatkan nilai terendah akan mendapatkan angka 5. Setelah mendapatkan hasil kredibilitas rasio maka dapat disimpulkan objek yang mana mendapatkan peringkat 1 sampai dengan peringkat 5 .

\section{HASIL DAN PEMBAHASAN}

Channel Youtube dari 4 Rekomendasi Channel Belajar Bahasa Inggris Terbaik di Youtube Indonesia, diantaranya :

\section{Aaron's English}

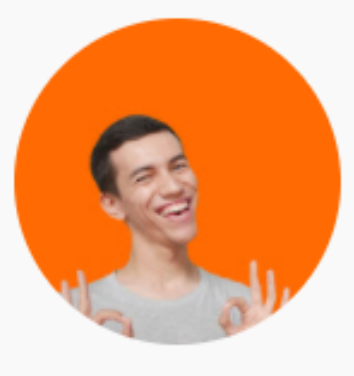

Aaron's English

$26,5 \mathrm{rb}$ subscriber $\cdot 77$ video

Your place to learn English

SUBSCRIBE and much more! Find tips,

Gambar 1. Channel Youtube Aaron's English

Sumber : https://www.youtube.com/channel/UCMKsqvjx8p1FXz2KK_SSTPg (akses pada 14-10-2021)

\section{Kampung Inggris LC - Language Center}

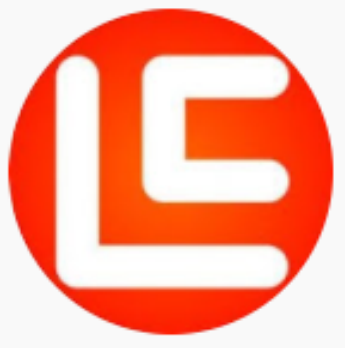

$$
\begin{aligned}
& \text { Kampung Inggris } \\
& \text { LC - Language... } \\
& \text { 1,2 jt subscriber } \cdot 1.123 \text { video } \\
& \text { Kampung Inggris LC Pare } \\
& \text { adalah salah satu Lembaga }
\end{aligned}
$$

Gambar 2. Channel Youtube Kampung Inggris LC - Language Center Sumber : https://www.youtube.com/c/kampunginggrislc (akses pada 14-10-2021)

\section{Guruku Mr D}




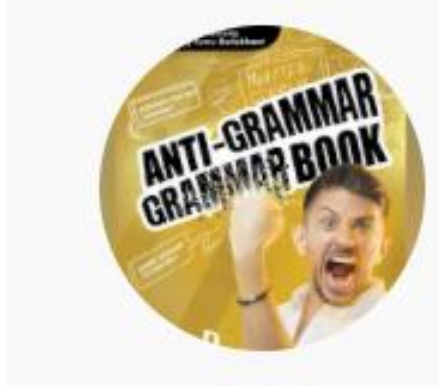

\section{guruku Mr D •}

$552 \mathrm{rb}$ subscriber $\cdot 247$ video

Belajar bahasa inggris

SUBSCRIBE

dengan seru! Video pelajaran

Gambar 3. Channel Youtube Guruku Mr D

Sumber : https://www.youtube.com/c/gurukuMrD (akses pada 14-10-2021)

\section{Sarah Johnson}

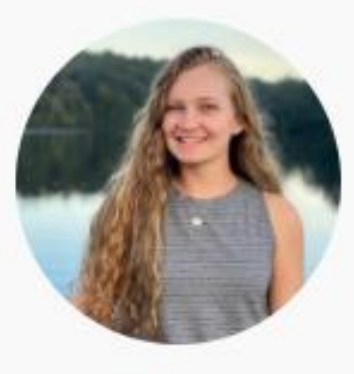

\section{Sarah Johnson $\bullet$}

877 rb subscriber $\cdot 351$ video

Apakah kamu suka dengar

SUBSCRIBE

bule bicara bahasa

Gambar 4. Channel Youtube Sarah Johnson

Sumber : https://www.youtube.com/channel/UCAPCdk6eRIDujOJpKCmBv9g (akses pada 14-10-2021)

Dari keempat channel Youtube 4 Rekomendasi Channel Belajar Bahasa Inggris Terbaik di Youtube Indonesia, peneliti menemukan nilai dari masing-masing variabel yang ada untuk menghitung rasio Dislikes to Subscriber dari setiap akun. Pada channel Youtube terdapat 6 variabel, diantaranya yaitu :

1. Likes

2. Dislikes

3. Subscribers

4. Video Post

5. Video Viewers

6. Video Comments

Dari keempat variabel tersebut peneliti hanya fokus untuk menemukan hasil dari 2 variabel, yaitu :

1. Dislikes

2. Subscribers

Dari kedua variabel tersebut kemudian dianalisa sehingga menemukan nilai rata-rata dari variabel dislikes dan variabel subscribers. Untuk menghitung nilai rata-rata dari variabel dislikes dan variabel subscribers yaitu dengan cara mengambil minimal 10 postingan kemudian di hitung sehingga menemukan nilai rata-rata dari masing-masing variabel. Berikut merupakan 
tabel nilai rata-rata dari masing-masing channel belajar Bahasa Inggris terbaik di youtube Indonesia, yaitu :

Tabel 1. Analisa Nilai Rata-Rata Nilai Variabel Dislikes dan Subscribers Channel Aaron's English

\begin{tabular}{|c|c|c|}
\hline \multicolumn{3}{|c|}{ Aaron's English } \\
\hline No. & Dislikes & Subscriber Ratio \\
\hline 1. & 12 & 26.200 \\
\hline 2. & 25 & 26.200 \\
\hline 3. & 13 & 26.200 \\
\hline 4. & 4 & 26.200 \\
\hline 5. & 8 & 26.200 \\
\hline 6. & 12 & 26.200 \\
\hline 7. & 2 & 26.200 \\
\hline 8. & 8 & 26.200 \\
\hline 9. & 4 & 26.200 \\
\hline 10 & 11 & 26.200 \\
\hline Total & \multicolumn{2}{|c}{} \\
\hline \multicolumn{2}{|c|}{9.9} & 26.200 \\
\hline
\end{tabular}

Sumber : Pengolah Data Excel

Tabel 2. Analisa Nilai Rata-Rata Nilai Variabel Dislikes dan Subscribers Channel Kampung Inggris LC Language Center

\begin{tabular}{|c|c|c|}
\hline \multicolumn{3}{|c|}{ Kampung Inggris LC - Language Center } \\
\hline No. & Dislikes & Subscriber Ratio \\
\hline 1. & 880 & 1.180 .000 \\
\hline 2. & 745 & 1.180 .000 \\
\hline 3. & 651 & 1.180 .000 \\
\hline 4. & 424 & 1.180 .000 \\
\hline 5. & 347 & 1.180 .000 \\
\hline 6. & 414 & 1.180 .000 \\
\hline 7. & 432 & 1.180 .000 \\
\hline 8. & 302 & 1.180 .000 \\
\hline 9. & 490 & 1.180 .000 \\
\hline 10 & 251 & 1.180 .000 \\
\hline Total & 493.6 & 1.180 .000 \\
\hline
\end{tabular}

Sumber : Pengolah Data Excel 
Tabel 3. Analisa Nilai Rata-Rata Nilai Variabel Dislikes dan Subscribers Channel Guruku Mr D

\begin{tabular}{|c|c|c|}
\hline \multicolumn{3}{|c|}{ Guruku Mr D } \\
\hline No. & Dislikes & Subscriber Ratio \\
\hline 1. & 54 & 552.000 \\
\hline 2. & 25 & 552.000 \\
\hline 3. & 69 & 552.000 \\
\hline 4. & 100 & 552.000 \\
\hline 5. & 43 & 552.000 \\
\hline 6. & 59 & 552.000 \\
\hline 7. & 128 & 552.000 \\
\hline 8. & 37 & 552.000 \\
\hline 9. & 10 & 552.000 \\
\hline 10 & 55 & 552.000 \\
\hline Total & & 58 \\
\hline
\end{tabular}

Sumber : Pengolah Data Excel

Tabel 4. Analisa Nilai Rata-Rata Nilai Variabel Dislikes dan Subscribers Channel Sarah Johnson

\begin{tabular}{|c|c|c|}
\hline \multicolumn{3}{|c|}{ Sarah Johnson } \\
\hline No. & Dislikes & Subscriber Ratio \\
\hline 1. & 612 & 875.000 \\
\hline 2. & 114 & 875.000 \\
\hline 3. & 79 & 875.000 \\
\hline 4. & 146 & 875.000 \\
\hline 5. & 56 & 875.000 \\
\hline 6. & 62 & 875.000 \\
\hline 7. & 49 & 875.000 \\
\hline 8. & 47 & 875.000 \\
\hline 9. & 29 & 875.000 \\
\hline 10 & 17 & 875.000 \\
\hline Total & 121.1 & 875.000 \\
\hline
\end{tabular}

Sumber : Pengolah Data Excel

Setelah menghitung nilai rata-rata tersebut, maka akan menemukan hasil akhir nilai rata-rata dari variabel dislikes dan subscribers. 
Tabel 5. Nilai Variabel Pada Channel Youtube 4 Rekomendasi Channel Belajar Bahasa Inggris Terbaik di Youtube Indonesia

\begin{tabular}{|c|c|c|c|c|}
\hline \multicolumn{5}{|c|}{ Tabel Nilai Masing-Masing Variable } \\
\hline Variable & Aaron's English & Kampung Inggris LC - Language Center & Guruku Mr D & Sarah Johnson \\
\hline Dislikes & 9.9 & 493.6 & 58 & 121.1 \\
\hline Subscriber Ratio & 26.200 & 1.180 .000 & 552.000 & 875.000 \\
\hline
\end{tabular}

Sumber : Pengolah Data Excel

Pada channel Youtube terdapat 10 rasio yang relevan digunakan untuk mengukur kredibilitas pada masing-masing akun. Namun pada penelitian kali ini hanya berfokus untuk menghitung Dislikes to Subscribers Ratio. Untuk menghitung kredibilitas dari masing-masing channel belajar Bahasa Inggris, peneliti menghitung dengan cara : variabel 1 akan dibagi dengan variabel 2 , sehingga ditemukan hasil analisa dari rasio tersebut.

Tabel 6. Hasil Perhitungan Rasio Channel Youtube

\begin{tabular}{|c|c|c|c|c|c|}
\hline \multicolumn{5}{|c|}{ Tabel Ratio } \\
\hline Ratio & Aaron's English & Kampung Inggris LC - Language Center & Guruku Mr D & Sarah Johnson & Karakteristik \\
\hline $\begin{array}{c}\text { Dislikes to } \\
\text { Subscriber Ratio }\end{array}$ & 0.3778625954198 & 418,3050847 & 0.0001050724637 & 0.1384 & Tinggi \\
\hline
\end{tabular}

Sumber : Pengolah Data Excel

Dislikes to Subscribers Ratio memiliki karakteristik yang tinggi, artinya semakin tinggi nilai yang dihasilkan maka semakin baik kredibilitas dari performa akun tersebut. Untuk memberikan peringkat pada masing-masing channel belajar Bahasa Inggris, peneliti memberikan angka 1 kepada vendor yang mendapatkan nilai tertinggi dan angka 4 untuk channel belajar Bahasa Inggris yang mendapatkan nilai terendah. Berikut merupakan tabel urutan nilai yang dihasilkan oleh masing-masing channel belajar Bahasa Inggris. 
Tabel 7. Nilai Rasio Channel Youtube 4 Rekomendasi Channel Belajar Bahasa Inggris Terbaik di Youtube Indonesia

\begin{tabular}{|c|c|c|c|}
\hline \multicolumn{2}{|c|}{ Tabel Peringkat } \\
\hline Aaron's English & $\begin{array}{c}\text { Kampung Inggris } \\
\text { LC - Language } \\
\text { Center }\end{array}$ & Guruku Mr D & Sarah Johnson \\
\hline 2 & 1 & 3 & 4 \\
\hline
\end{tabular}

Sumber : Pengolah Data Excel

Dari Tabel Nilai Rasio Channel Youtube 4 Rekomendasi Channel Belajar Bahasa Inggris Terbaik di Youtube Indonesia dapat simpulkan bahwa Kampung Inggris LC Language Center mendapatkan nilai tertinggi untuk Dislikes to Subscribers Ratio. Sedangkan akun TikTok Sarah Johnson mendapatkan nilai terendah untuk rasio ini. Jadi, pada penelitian ini Kampung Inggris LC - Language Center memiliki kredibilitas performa yang lebih baik dibandingkan dengan channel belajar Bahasa Inggris yang lainnya.

\section{KESIMPULAN}

Tujuan dari penelitian ini adalah mengetahui kredibilitas performa dari channel Youtube 4 Rekomendasi Channel Belajar Bahasa Inggris Terbaik di Youtube Indonesia menggunakan Dislikes to Subscribers Ratio. 4 Rekomendasi Channel Belajar Bahasa Inggris Terbaik tersebut diantaranya : Kampung Inggris LC - Language Center, Aaron's English, Guruku Mr D, dan Sarah Johnson. Dari keempat channel Bahasa Inggris tersebut dapat disimpulkan bahwa :

1. Peringkat pertama diraih oleh channel Kampung Inggris LC - Language Center dengan nilai tertinggi yaitu 0.3778625954198

2. Peringkat kedua diraih oleh channel Aaron's English dengan nilai 418.3050847

3. Peringkat ketiga diraih oleh channel Guruku Mr D dengan nilai 0.0001050724637

4. Peringkat keempat diraih oleh channel Sarah Johnson dengan nilai 0.1384 


\section{DAFTAR PUSTAKA}

Arifin, R. (2016). Pengaruh youtube sebagai alat komunikasi massa. Pengaruh Youtube Sebagai Alat Komunikasi Massa, 1969, 9-26. http://eprints.umm.ac.id/40615/3/BAB II.pdf

Chandra, E. (2018). Youtube, Citra Media Informasi Interaktif Atau Media Penyampaian Aspirasi Pribadi. Jurnal Muara Ilmu Sosial, Humaniora, Dan Seni, 1(2), 406. https://doi.org/10.24912/jmishumsen.v1i2.1035

Hendika Permana, I. P. (2021). Analisis Rasio Pada Akun Youtube Untuk Penelitian Kualitatif Menggunakan Metode Ekploratif. Jurnal Ilmiah Media Sisfo, 15(1), 40. https://doi.org/10.33998/mediasisfo.2021.15.1.970

Mangole, K. D. B., Himpong, M., \& Kalesaran, E. R. (2017). Pemanfaatan Youtube dalam Meningkatkan Pengetahuan Masyarakat di Desa Paslaten Kecamatan Remboken Minahasa. Jurnal Acta Diurna, 6(4), 1-15. https://ejournal.unsrat.ac.id/index.php/actadiurnakomunikasi/article/download/18359/17 887

Nurhadi, Z. F. (2020). Youtube Sebagai Media Informasi Kecantikan Generasi Millenial. Commed: Jurnal Komunikasi Dan Media, 4(2), 170. https://doi.org/10.33884/commed.v4i2.1585

Onainor, E. R. (2019). 済無No Title No Title No Title. 1, 105-112.

Setiadi, E. F., Azmi, A., \& Indrawadi, J. (2019). Youtube Sebagai Sumber Belajar Generasi Milenial. Journal of Civic Education, 2(4), 313-323. https://doi.org/10.24036/jce.v2i4.135

Surandika, A. A. A. G. S. A. J. (2020). Penggunaan Youtube sebagai Media Pembelajaran Jarak Jauh pada Kelas III Sekolah Dasar Islam An - Nizomiyah. Prosiding SEMNASLIT LPPM UMJ, 161-171. https://jurnal.umj.ac.id/index.php/semnaslit/article/view/8781

Thanissaro, P. N., \& Kulupana, S. (2015). Buddhist teen worldview: Some normative background for health professionals. Contemporary Buddhism, 16(1), 28-42. https://doi.org/10.1080/14639947.2015.1006801

Wirga, E. W. (2016). Content Analysis on Youtube Social Media to Support Political Campaign Strategies. Jurnal Ilmiah Informatika Dan Komputer, 21(100), 14-26. https://ejournal.gunadarma.ac.id/index.php/infokom/article/view/1716 